\title{
RECREATIVE INDUSTRY, INNOVATIONS AND THE BULGARIAN EDUCATIONAL MODEL FOR SPECIALISED STAFF
}

\author{
Bistra Dimitrova \\ National Sports Academy "V. Levski”
}

\begin{abstract}
Key words: Recreative industry, innovations, Bulgarian educational model, specialised staff, Wellness culture \& new EU profession.
\end{abstract}

Introduction: Over the last five years, people actively talk about Wellness tourism and Recreative programs (Ignatov, 2012), but it is still developing spontaneous, without a clear concept, unable to compete with even the countries of Central Europe due to lack of specialized personnel. Service standards in the industry have not been introduced, worldwide not given a specific definition, and global tourism defined as the strongest niche - "SPA and Wellness sector" (Dimitrova, 2011). Significantly increased the proportion of active healthy holidays, as in 2016 Wellness tourism practiced more than 4 million People worldwide. Wellness methodologies and practices can be seen as "... creating polyvalent Wellness \& Spa culture ..."(Dimitrova, 2009), it is important to "... discuss problems recuperation significance of physical activity in the aquatic environment and the direct link to improving the quality of life and health status of the practitioners ..." (Dimitrova, 2012). According the Summary Report, of the Global Wellness institute (Ellis, S., 2013), globally find highly qualified staff for Wellness centres is a major problem. The U.S. economic analysts call this fact a "War for talents". According the research team of the Global Wellness Institute, in the study of the industry, which results are presented in the Economy Report (2014): “... $95 \%$ of the leaders of the SPA \& Wellness industry said they are facing serious problems in recruiting Wellness \& SPA managers / directors with right mix of skills and experience. Over $52 \%$ of the owners of the centres stated that the issue of qualification of the staff remains the same or even worse ..." (Dimitrova, 2014). The needs of the practice grow, and definitely not enough staff (Polimenov, 2014). Therefore, a person's particular situation in which the dynamics of the SPA \& Wellness tourism on the demand for specialized packages outstrips with great growth rates operation of services with qualified personnel certified through educational programs (Dimitrova, Donev, 2006), fellowships, training seminars or received certified competencies. On international level, according the research team of the Global Wellness Institute, in the study of the industry, which results are presented in the Economy Report (2014) - highlighted the fact that wellness tourism is expanding rapidly, demanding for more staff than existing. The global wellness tourism market is currently worth 425 billion euro and $36 \%$ of that spending is generated by Europe (Polimenov, 2014). Six of the top 10 world wellness tourism destinations are in Europe (Treneva, 2013). Growth forecasts suggest opening up the potential of Eastern Europe (Polimenov, 2014). The European wellness industry is aware that in order to maintain its leading positions and quality, ensuring relevant training is a critical success factor (Trendafilov, Dimitrova, 2013), both for current and future employees involved in the provision of services to ensure the satisfactory delivery of the tasks assigned to them (Nesheva, 2015) and "...the wellness practices as a cultural phenomenon has a positive impact on health..." (Staneva, 2014).

Methodology: The aim of the publication is to establish the actual quality of the educational programs in the Balkan countries (Bulgaria, Romania, Serbia, Montenegro, Greece, Albania and Macedonia) and setting out the requirements for specialized staff in Bulgarian Recreative Industry and Niche tourism. Object of the study were 243 costumes (from a study of the Wellness Institute Bulgaria) senior professionals from various SPA \& Wellness \& Thalasso centres (employees, executives, investors, entrepreneurs, managers, 'company managers, representatives of professional organizations and the executive power, master and PhD students in NSA), which conducted the Bal- 
kan survey in support of the experts mapping of the Wellness industry and educational programs on regional level. NGOs supporting this survey was: the Balkan Cluster for Health, Wellness \& SPA tourism, the Federation of sport pedagogue of Republic of Macedonia, the vocational training centre "Progress and knowledge" from Sofia, the Medical SPA association of Montenegro, the Wellness academy of Serbia, the Romanian foundation "Amphytheatru", Wellness institute of Greece and the Bulgarian Association for Geomedicine and Geotherapy). The survey is executed during the period: 2016, December to 2017 March, as a part of the Wellness Instructor VET Course (WELVET), Erasmus + action key 2, Cooperation for innovation and the exchange of good practices, strategic partnerships: 2016-1-BG01-KA202. Our work hypothesis is built on the assumption that joint action is needed, in collaboration with the professional associations and NGOs for the development and adoption of state regulatory tools for the education of specialized staff for the Recreative and Wellness industry and the Niche tourism. The applied method is a psychometric registration of the costumers (different structural levels) opinions, analysis by weight and the ranking of significance and systematization of the governmental statistical data for the educational programs in different cognitive levels, by countries. The expert's analysis, of the WELVET survey in Bulgaria, was identified, by finding 6 indicators for ranking the Wellness facilities and 6 indicators for the customer expectations for the Wellness staff that they ranked by importance. We calculate the weight of each indicator - in points and in percentages of the entire unity.

Results: On the basis of the survey we believe that joint action will produce: Setting standards for categorization of Wellness \& SPAs and quality assessment procedures and services; provide specialized training of personnel with specialized secondary and higher educational content (in Bulgaria, NSA "V. Levski" are accredited "Bachelor", "Master" and "Doctoral" degree programs in the professional fields: 7.6. Sport and 7,5. Health Care). The WELVET project's core intellectual output, a VET course for the emerging "wellness instructor" occupation, is addressing a pressing need of the European wellness tourism industry, namely the lack of trained staff to deliver high quality specialized customer service. Our ambition is to also ensure and propose a unique delivery method by design- ing, testing and producing a WELVET mobile app., in order to ensure free and open access innovative training embedded in the digital era. The WELVET project further resonates the main new features and meta priority lines of Erasmus+ such as dissemination and exploitation of results: the project consortium covers 4 main regions of EU - South-Eastern, Central, North and Western Europe, open access to education products and multilingualism (products in 5 languages: EN, BG, EE, MK, DE). Important it is to create "... educational Wellness modules and levels of education in the teaching and training process ..." in the secondary and the higher education (Dimitrova, (Димитрова), 2012).

Discussion: For the first time is presented the statistical data 2017, for the Balkan region and the educational models from secondary school to "Doctoral degree" programs.

Table 1 summarized the existing education and training programs worldwide by continents in 2014. This information is considered to be as accurate as possible, from the Global Wellness Institute / by his research team / but the figures are permissible standard error. Perhaps there are other providers of special education who are not identified and were noted in the study - as is the Bulgarian case. Providers listed in the table are based on data of the research team of SRI, according to information compiled: online, by email, site survey or filed by telephone. The survey of the WELVET project show for the first time, the existing type of programs for specialised staff on the Balkan Region and some other European countries. Providers of continuing education are also new, fragmented and no "proven" model for effective delivery of training for employees already working in the Wellness sector. At present special problems in management of Wellness business concern (Ellis, 2013):

1.The challenges associated with current / future SPA \& Wellness managers; 2.The requirements for a high level of skills acquired in their careers / path of growth; 3.Challenges in taking a management position, which requires interdisciplinary knowledge and skills combined with an understanding of the Wellness Culture and people motivation for healthy life style. In our original psychometric experiment, the main factors for high quality and preferences for one Wellness Centre, according to the majority of customers (Table 2) / experts "The centre must 
Table 1:

Types of educational programs and training for SPA \& Wellness worldwide

S ummary of Wellness \& S PA Management - Education \& Training programs on the sector

\begin{tabular}{|c|c|c|c|c|}
\hline \multirow[b]{2}{*}{ Destinations } & \multirow{2}{*}{$\begin{array}{l}\text { Total number of } \\
\text { University / College } \\
\text { specific programs }\end{array}$} & \multirow[b]{2}{*}{$\begin{array}{l}\text { Total number of } \\
\text { University / College }\end{array}$} & \multicolumn{2}{|c|}{ Private companies } \\
\hline & & & $\begin{array}{l}\text { Bachelor / Master } \\
\text { / Doctoral Degree }\end{array}$ & $\begin{array}{l}\text { Short courses, } \\
\text { seminars, } \\
\text { Certification }\end{array}$ \\
\hline \multicolumn{5}{|c|}{ Worldwide (2014) } \\
\hline Caribbean region & 3 & 1 & 1 & 7 \\
\hline Eu rope & 9 & 3 & 8 & 15 \\
\hline Latin America & 4 & 1 & - & 3 \\
\hline Middle East & 1 & 1 & - & - \\
\hline North America & 16 & 7 & - & 9 \\
\hline In the world & 41 & 15 & 2 & 24 \\
\hline \multicolumn{5}{|c|}{ Balkan Region of Europe (2017) } \\
\hline Bulgaria & 7 & 3 & $6+1 \mathrm{PhD}$ & 2 \\
\hline Mace don ia & 2 & - & - & 2 \\
\hline Austria & 4 & 2 & $1 \mathrm{BD}+1 \mathrm{MD}$ & 4 \\
\hline Estonia & 3 & - & - & 3 \\
\hline Romania & 1 & - & - & 1 \\
\hline Greece & 1 & - & - & 1 \\
\hline Montenegro & 1 & - & - & 1 \\
\hline Serbia & 2 & - & - & 2 \\
\hline Turkey & 1 & - & - & 1 \\
\hline Albania & - & - & - & - \\
\hline Total & 22 & 6 & 9 & 17 \\
\hline
\end{tabular}

Table 2:

Matrix of the opinions of surve yed experts for evaluation of the quality of Wellness facilities

\begin{tabular}{|c|c|c|c|c|c|c|c|c|}
\hline \multirow{3}{*}{ Indicators } & 1 & 2 & 3 & 4 & 5 & 6 & \multirow{3}{*}{ Sum } & \multirow{3}{*}{ Rang } \\
\hline & 16 & 15 & 14 & 13 & 12 & $/ 1$ & & \\
\hline & un. & un. & un. & un. & un & un. & & \\
\hline \multirow{3}{*}{$\begin{array}{l}\text { 1. The centre must employ highly } \\
\text { qualified and trained personnel, selected } \\
\text { according to specific criteria like } \\
\text { education, skills and experience. }\end{array}$} & 88 & 12 & 1 & 1 & \multirow{3}{*}{ - } & \multirow{3}{*}{ - } & 102 & \multirow[b]{3}{*}{ I } \\
\hline & $86 \%$ & $12 \%$ & $1 \%$ & $1 \%$ & & & people & \\
\hline & 486 & 60 & 4 & 3 & & & $\begin{array}{l}553 \text { Units } \\
\text { Kally }\end{array}$ & \\
\hline \multirow{3}{*}{$\begin{array}{l}\text { 2. The centre must meet standards in the } \\
\text { quality of Wellness services and EU } \\
\text { standards regarding wellness \& spa } \\
\text { nroduntc. }\end{array}$} & 9 & 66 & 15 & 6 & 5 & 1 & 102 & \multirow{3}{*}{ II } \\
\hline & $8.50 \%$ & $65.50 \%$ & $14.50 \%$ & $5.50 \%$ & $5 \%$ & $1 \%$ & $100 \%$ & \\
\hline & 54 & 330 & 60 & 18 & 10 & 1 & 473 & \\
\hline \multirow{3}{*}{$\begin{array}{l}\text { 3. The centre must have state-of-the-art } \\
\text { facilities and equipment }\end{array}$} & 4 & 3 & 70 & 6 & 10 & 9 & 102 & \multirow{3}{*}{ III } \\
\hline & $3.50 \%$ & $2.50 \%$ & $69 \%$ & $5.50 \%$ & $9 \%$ & $8.50 \%$ & $100 \%$ & \\
\hline & 24 & 15 & 280 & 18 & 20 & 9 & 366 & \\
\hline \multirow{3}{*}{$\begin{array}{l}\text { 4. The centre lieeds a detarlea } \\
\text { investment project plan concerning the } \\
\text { areas of wellness \& spa business } \\
\text { davalonmant }\end{array}$} & 1 & 12 & 6 & 42 & 4 & 37 & 102 & \multirow{3}{*}{ IV } \\
\hline & $1 \%$ & $12 \%$ & $5.50 \%$ & $41.50 \%$ & $3.50 \%$ & $36.50 \%$ & $100 \%$ & \\
\hline & 6 & 60 & 24 & 126 & 8 & 37 & 261 & \\
\hline \multirow{3}{*}{$\begin{array}{l}\text { 5. The centre must have effective } \\
\text { structure of governance and procedures } \\
\text { for management }\end{array}$} & & 4 & 6 & 20 & 72 & \multirow{3}{*}{-} & 102 & \multirow{3}{*}{$\mathrm{V}$} \\
\hline & - & $3.50 \%$ & $5.50 \%$ & $9 \%$ & $71.50 \%$ & & $100 \%$ & \\
\hline & & 20 & 24 & 60 & 144 & & 248 & \\
\hline \multirow{3}{*}{$\begin{array}{l}\text { 6. The centre must have excellent image } \\
\text { and competitiveness. }\end{array}$} & & 5 & 4 & 27 & 11 & 55 & 102 & \multirow{3}{*}{ VI } \\
\hline & - & $5 \%$ & $3.5 \%$ & $26.50 \%$ & $10 \%$ & $54.50 \%$ & $100 \%$ & \\
\hline & & 25 & 14 & 81 & 22 & 55 & 197 & \\
\hline
\end{tabular}


employ highly qualified and trained personnel, selected according to specific criteria like education, skills and experience" (grades weight 553 units 86\%) and "The centre must meet standards in the quality of services and EU standards regarding wellness \& spa centres" (Ranks weight 473 units $65,5 \%)$. Third and fourth are classified "The centre must have state-of-the-art facilities and equipment" (Ranks weight 366 units - 69\%) and "The centre needs a detailed investment project plan concerning the areas of wellness \& spa business development" (rang. weight 261 units - 41,5\%). Indicators: "The centre must have effective structure of governance and procedures for management" and "The centre must have excellent image and competitiveness", received (rang. Weight 209 units - 71,5\%) and (rang. Weight 197 units - 54,5\%). The ranking of the other indicators / 7 to 10 place /, studied by the Wellness Institute Bulgaria, are as follows: a large assortment of Wellness services; optimal pricing strategy; flexible marketing policy; favourable conditions of work and promotion of employees, but for the WELVET study the Consortium makes his preference only for 6 statements. From the data analysis we find, that the first and second place are based on the professional qualifications of the personnel and the effectiveness of the implementation of services. The experts determination of the priority indicators in the study, conducted to their ranking, should be considered when uniform standards will be introduced (in accordance with the EU criteria) by all public authorities responsible for the National categorization of Wellness\&Spa facilities and the National certification of staff in the wellness sector. A crucial need of training programs is established, during the WELVET survey in the partner countries. Future professionals in the wellness industry needs a stable knowledge and competencies for effective organizational and methodical (Intellectual and practical knowledge and skills for different procedures and healthy influences, based on the natural resources and holistic approaches), with a high level of motivation to offer and perform quality services tailored to the needs of wellness customers and promote their interests. In this connection it is necessary to activate the professional contacts between academic units, VET course centres, Secondary schools, professional educational bodies, for build a Bridge between the theory and the wellness business and Industry sectors (with

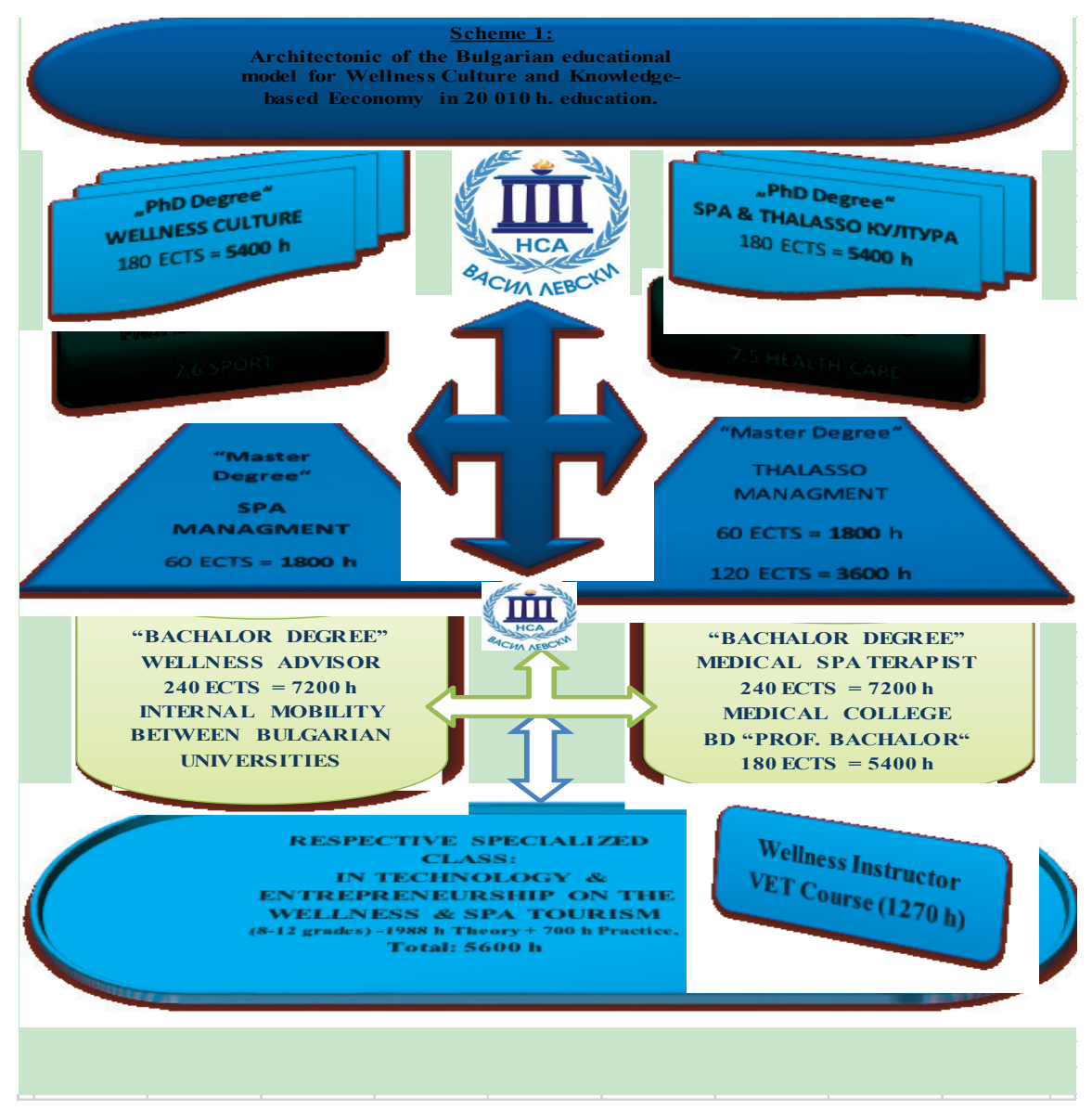


real practice in real professional environment).

The elaborated, in our Erasmus + WELVET project - Curriculum, Syllabus and Job profile are intellectual outputs are with high added value to the EU educational and labour policies, which expect to ensure inclusive smart growth.

For the first time is presented the full architectonical vertical of the Bulgarian educational model from secondary school to "Doctoral degree" programs (Table 3) - successful accredited with excellence by the external experts from the Bulgarian Agency for accreditation and evaluation for the Bulgarian University: National Sports Academy "V. Levski" - Educational Leader, with 5 accredited Wellness \& SPA \& Thalasso programs - from "bachelor degree" to "Doctoral" degree in 2 professional fields: 7.6. Sport and 7.5. Health Care.

\section{Conclusions:}

In conclusion, on the basis of our survey, we propose conclusions, as the following:

1. On European level, the Recreative industry has needs for well-educated Staff;

2. The Bulgarian model has 7 accredited programs for Wellness \& SPA managers and the requirements for a high level of skills acquired in their education;

3. In Europe and the Balkans, to take a management position, requires interdisciplinary knowledge and skills combined with an understanding of the Wellness Culture and people motivation for healthy life style.

4. Bulgaria is the Balkan educational leader in the Wellness sector;

5. Europe is building her won quality standards and criteria on educational and professional competencies of specialized staff for Wellness services.

\section{References}

DIMITROVA, B., Y. DONEV.(2006). Плувни спортове в училище. Монография. [Swimming sports in school. In Bulgarian.] София: Издателство Авангард Прима. DIMITROVA, B. (2009). SPA култура и аква практики. Учебник за ОКС „Магистът“. [SPA culture and aqua practices. In Bulgarian.] София: Издателство Авангард Прима.

DIMITROVA, B. N. DEDE (2011). Акваспининг като антистресова превенция на здравето. Трета международна научна конференция: Оптимизация и иновации в учебно-тренировъчния процес. [Aqua spinning as anti-stressing health prevention. 3th International Scientific conference: Optimization and innovation in educational training process.] Сборник доклади, 2011, p.146-153, Department of Physical education and sport, Sofia University «St. Kl. Ohridski.

DIMITROVA, B. (2012). Аква практики [Aqua practices. In Bulgarian.] София: Издателство Авангард Прима.

DIMITROVA, B. (2014). The enotherapy as an effective financial instrument for the wine tourism. International Scientific Conference for Tourism "SPA and wine"- part of the Culture corridor - cultural routes. Proceedings ( $\mathrm{p}$. 55-61). Blagoevgrad. Faculty of Economy, Tourism department. SW University.

ELLIS, S. (2013). The global wellness tourism economy 2013. Report of the Global Wellness Tourism Congress (Delhi, India). Ed. Global wellness and Spa Association, Miami, USA.

GLOBAL WELLNESS INSTITUTE (2014). Economic Report. Miami, USA, 2014. (https://www.globalwellnessinstitute.org/).

IGNATOV, I. (2012). Water in the Human Body is Information Bearer about Longevity, World Scientific Conference "Chemistry, Physics and Biology of Water" (www. waterconf.org). Acts 2012, (p.57). Vermont Photonics, NY.

NESHEVA, I. (2015). Benefits of the physical activity and the elaborated program mental prevention gym for women with normal pregnancy. Research in Kinesiology, 43(2), 210-214.

STANEVA, K. 2016. An evaluation of the potential of Cross- border region Bulgaria-Serbia for development of Wellness, medical SPA and SPA tourism - possibilities and perspective. ATLAS Tourism and Leisure Review, ISSN2468-6719, Health, Wellness and Spa Tourism in the Balkans, Netherlands. 3(2016), 43-58.

TRENDAFILOV, D., \& DIMITROVA, B. (2013). Aqua Spinning as anti-stress health prevention. Acts of Conference "Physical education and sport". Montenegro, 2013, No 37-39 / XI, (p. 454-460. ISSN1451-7485 (9771-4517-48001).

TRENEVA, V. (2013). Селекция в спорта канукаяк [Selection in canoe-kayak sport. In Bulgarian.] Национална спортна академия „В. Левски“. НСА Прес.

POLYMENOV, M. (2014). Иновации в ресторантьорството [Innovations in restaurant management. In Bulgarian.] София: Авангард Прима.

Correspondence: Bistra Dimitrova, E-mail: $\underline{\text { dimi- }}$ trova.bistra@yahoo.com

National Sports Academy "Vassil Levski" Sofia,

Depart. Aquatic sports, Studentski grad 1700 Sofia Bulgaria 